\title{
Ochrona zabytków nieruchomych jako zadanie samorządu terytorialnego. Zagadnienia wybrane
}

\author{
Maria Karcz-Kaczmarek \\ Dr, Uniwersytet Łódzki, Wydział Prawa i Administracji, \\ Katedra Prawa Administracyjnego i Nauki Administracji \\ http://dx.doi.org/10.18778/8088-114-3.24
}

\section{Wprowadzenie}

Reaktywowany w wyniku reformy ustrojowej z 1990 roku samorząd terytorialny, obejmujący pierwotnie wyłącznie gminy ${ }^{1}$, zobowiązany został na mocy znowelizowanego wówczas przepisu art. 11 ust. 1 ustawy z dnia 15 lutego 1962 r. o ochronie dóbr kultury² do dbałość o dobra kultury oraz zapewnienia warunków prawnych, organizacyjnych i finansowych dla ich ochrony ${ }^{3}$. Zadania te uwzględniane miały być w miejscowych planach zagospodarowania przestrzennego, w budżetach oraz $\mathrm{w}$ prawie miejscowym. Ponadto na wójtów lub burmistrzów (prezydentów miast) gmin, w których nie zostali powołani konserwatorzy zabytków, nałożono obowiązek wydawania zarządzeń w celu zabezpieczenia zabytków w nagłych przypadkach ${ }^{4}$. Ochrona zabytków i opieka nad nim jako zadanie własne gmin do ustawy o samorządzie gminnym wprowadzona została dopiero na mocy art. 126 ustawy z dnia 23 lipca 2003 r. o ochronie zabytków i opiece nad zabytkami ${ }^{5}$. Zgodnie $\mathrm{z}$ tą ustawą ochrona ${ }^{6}$ zabytków polega, w szczególności, na podejmowaniu przez organy administracji

1 Ustawa z dnia 8 marca 1990 r. o samorządzie terytorialnym (tekst pierwotny Dz.U. Nr 16, poz. 95).

2 Tekst jedn. Dz.U. z 1999, Nr 98, poz. 1150 ze zm., zwana dalej u.o.d.k.

3 Por. art. 11 u.o.d.k.

4 Do czasu wejścia w życie ustawy o samorządzie terytorialnym zadania te realizowane były przez prezydia powiatowych i miejskich rad narodowych, w których nie zostali powołani konserwatorzy zabytków, oraz prezydia rad narodowych niższego stopnia. Por. tekst pierwotny art. 11 u.o.d.k. (Dz.U. z 1962, Nr 10, poz. 48).

5 Tekst jedn. Dz.U. z 2014, poz. 1446 ze zm. (zwana dalej u.o.z.o.z.)

6 Por. art. 4 u.o.z.o.z. 
publicznej, w tym organy jednostek samorządu terytorialnego, działań mających na celu zapewnienie warunków prawnych, organizacyjnych i finansowych umożliwiających trwałe zachowanie zabytków oraz ich zagospodarowanie i utrzymanie oraz zapobieganie zagrożeniom mogącym spowodować uszczerbek dla wartości zabytków. Ponadto ochrona zabytków ma udaremniać niszczenie i niewłaściwe z nich korzystanie, przeciwdziałać kradzieży, zaginięciu lub nielegalnemu wywozowi zabytków za granicę. Ochrona zabytków, w myśl ustawy z 2003 roku, realizowana jest także poprzez kontrolę stanu zachowania i przeznaczenia zabytków. Względy ochrony zabytków uwzględniane są także w planowaniu i zagospodarowaniu przestrzennym oraz przy kształtowaniu środowiska. Z kolei opieka nad zabytkami, sprawowana przez ich właścicieli lub posiadaczy, polega na podejmowaniu określonych ustawowo działań zmierzających do zachowania zabytku w jak najlepszym stanie ${ }^{7}$. Zgodnie z ustawą z 2003 r. ochronie i opiece ${ }^{8}$ podlegają, bez względu na stan ich zachowania, zabytki nieruchome będące, w szczególności, krajobrazami kulturowymi, układami urbanistycznymi, ruralistycznymi i zespołami budowlanymi, bądź dziełami architektury lub budownictwa (budownictwa obronnego). Powołana ustawa odnosi się także do obiektów techniki (a zwłaszcza kopalń, hut, elektrowni i innych zakładów przemysłowych), cmentarzy, parków, ogrodów (i innych form zaprojektowanej zieleni) oraz miejsc upamiętniających wydarzenia historyczne lub działalność wybitnych osobistości (lub instytucji). Należy podkreślić, że ustawowy katalog zabytków nieruchomych jest jedynie przykładowy, co oznacza, że jednostki samorządu terytorialnego mogą objąć ochroną także inne, niewymienione wprost w przepisie art. 6 u.o.z.o.z., miejsca ważne dla narodowego dziedzictwa kultury.

Początek transformacji ustrojowej cechował się w wielu wypadkach drapieżnością $\mathrm{w}$ celu szybkiego wzbogacenia się. Stan taki dotyczył w szczególności przekształceń w sferze nieruchomości, które stawały się niejednokrotnie „łupem” dla kształtującej się wówczas warstwy pseudo-przedsiębiorców, dla których idee ochrony zabytków i ich otoczenia nie miały większego znaczenia. Działania te negatywnie odbiły się w szczególności na pozostających dotychczas w państwowych rękach zespołach

7 Por. art. 5 u.o.z.o.z.

8 J. Sługocki zwrócił uwagę, iż ustawa z 2003 r. nieprecyzyjnie i niekonsekwentnie posługuje się terminami „opieka” i „ochrona” nad zabytkami. Brak wyraźnego rozróżnienia tychże pojęć wpłynął na intuicyjne posługiwanie się nimi w innych ustawach, np. ustawach samorządowych lub dotyczących administracji rządowej. J. Sługocki, Próba doprecyzowania pojęć prawnych na przykładzie ustawy z 23 lipca 2003 r. o ochronie zabytków i opiece nad zabytkami, www.wuwr.com.pl/online-texts/download/27. html (dostęp 10.07.2015). 
dworsko-pałacowych wraz z przyległymi do nich parkami i ogrodami 9 Po 1990 roku na masową skalę dokonywano przekształceń własnościowych mających na celu obejście wymogu uzyskania zgody Ministra Kultury i Sztuki na przeniesienie własności zabytku będącego w zasobie Skarbu Państwa ${ }^{10}$. Niestety, miały wówczas miejsce także nieracjonalne podziały nieruchomości zabytkowych, które z uwagi na ich rozdrobnienie uległy zniszczeniu, bądź całkowicie utraciły swój dotychczasowy zabytkowy, historyczny charakter. Co warte zauważenia, pozycja prawna wojewódzkiego konserwatora zabytków w sprawach dotyczących podziałów nieruchomości zabytkowych jest uzależniona od trybu ich dokonywania. W myśl art. 96 u.g.n. ${ }^{11}$, jeżeli podział nieruchomości dokonywany jest na podstawie decyzji wójta (burmistrza albo prezydenta miasta) zatwierdzającej podział, to w odniesieniu do nieruchomości wpisanej do rejestru zabytków wymagane jest uzyskanie pozwolenia wojewódzkiego konserwatora zabytków. Wymogu uzyskania wskazanego pozwolenia nie stosuje się natomiast do podziałów dokonywanych w drodze sądowej. W tym przypadku sąd zasięga jedynie opinii wojewódzkiego konserwatora zabytków. W ocenie $\mathrm{NSA}^{12}$ rozstrzygnięcie konserwatora zabytków $\mathrm{w}$ formie decyzji administracyjnej w trybie sądowego podziału jest niedopuszczalne. Jedyną dozwoloną prawnie formą wyrażenia stanowiska konserwatorskiego odnośnie sądowego podziału nieruchomości jest bowiem opinia. Opinia ta nie ma charakteru wiążącego, stanowi jedynie uzewnętrznienie stanowiska organu na użytek sprawy sądowej. Sąd administracyjny stwierdził, że „organy administracji wobec prowadzonego przez sąd powszechny postępowania [o zniesienie współwłasności] nie mają kompetencji do prowadzenia postępowania administracyjnego w sprawie podziału" ${ }^{13}$. Z punktu widzenia ochrony zabytków odmienne traktowanie uprawnień konserwatora zabytków w zależności od trybu dokonywania podziału nieruchomości budzi pewne wątpliwości. Stanowisko konserwatora zabytków jako organu profesjonalnego i wyspecjalizowanego w problematyce ochrony zabytków powinno być uwzględniane. Ani organ administracji publicznej (wójt) ani sąd powszechny

9 Zob. J. Pruszyński, Dziedzictwo kultury Polski. Jego straty i ochrona prawna, tom II, Kraków 2001, s. 374-377; J. Sługocki, Problemy prawne ochrony zabytkowych parków dworsko-pałacowych, [w:] Dobra chronione w prawie administracyjnym, Łódź 2014, s. 226.

10 J. Sługocki, Opieka nad zabytkiem nieruchomym. Problemy administracyjnoprawne, Warszawa 2014, s. 97.

11 Ustawa z dnia 21 sierpnia 1997 r. o gospodarce nieruchomościami (tekst jedn. Dz.U. z 2015, poz. 1774 ze zm., zwana dalej u.g.n.).

12 Wyrok z dnia 23 sierpnia 2011 r., sygn. akt II OSK 432/11, http://orzeczenia.nsa. gov.pl (dostęp 10.06.2015).

13 Tamże. 
nie musi bowiem posiadać wiedzy i doświadczenia konserwatorskiego. Biorąc pod uwagę przepis art. 95 u.o.z.o.z., zgodnie z którym wojewódzki konserwator zabytków może w postępowaniu cywilnym w sprawach ochrony zabytków występować na prawach strony, stwierdzić można, że wola ustawodawcy było zapewnienie czynnego udziału podmiotu wyspecjalizowanego w sprawach ochrony zabytków w postępowaniach ich dotyczących (postępowaniem takim z pewnością jest postępowanie dotyczące podziału nieruchomości wpisanej do rejestru zabytków). Być może zasadnym byłoby wprowadzenie "ochronnych” rozwiązań prawnych, które gwarantowałyby zachowanie dotychczasowego spójnego charakteru nieruchomości zabytkowej. Rozwiązania takie nie powinny jednak stanowić nadmiernej ingerencji w uprawnienia właścicieli tychże nieruchomości zabytkowych w przypadku ich sądowego podziału.

Dokonana na mocy przepisów ustawy z dnia 10 maja 1990 r. ${ }^{14}$ komunalizacja mienia ogólnonarodowego (państwowego), które z mocy prawa stało się mieniem gmin $\mathrm{w}$ wielu przypadkach negatywnie wpłynęła na stan zachowania zabytków. Uwłaszczone we wskazany sposób gminy (później także pozostałe jednostki samorządu terytorialnego) dokonywały podziałów nieruchomości i prywatyzowały zabytki na rzecz osób trzecich. Sprawowanie rzeczywistej ochrony nad zabytkiem nieruchomym pozostającym po dokonanym podziale w rękach wielu różnych właścicieli (osób fizycznych lub/oraz osób prawnych) było często iluzoryczne ${ }^{15}$. Należytej ochrony prawnej zabytków nie dawały także obowiązujące wówczas przepisy ustawowe, $\mathrm{w}$ tym przepisy o gospodarce nieruchomościami ${ }^{16}$. Do dnia 17 listopada 2003 r. przepis art. 13 ust. 4 u.g.n. stanowił, że sprzedaż, zamiana, darowizna lub oddanie w użytkowanie wieczyste nieruchomości wpisanych do rejestru zabytków, a także wnoszenie tych nieruchomości jako wkładów niepieniężnych (aportów) do spółek, wymagało uzyskania zgody właściwego wojewódzkiego konserwatora zabytków wyłącznie w odniesieniu do nieruchomości stanowiących własność Skarbu Państwa. W stosunku do nieruchomości stanowiących własność gminy (później nieruchomości stanowiących własność jednostki samorządu terytorialnego) ustawa wymagała jedynie uzyskania opinii właściwego wojewódzkiego konserwatora zabytków. Dla ważności dokonywanej czynności prawnej decydujące znaczenie miał sam fakt wyrażenia opinii przez wojewódzkiego konserwatora zabytków. Negatywna opinia konserwatora nie pozbawiała bowiem gminy możliwości działania ${ }^{17}$. Z uwagi na niewiążący charakter

14 Przepisy wprowadzające ustawę o samorządzie terytorialnym i ustawę o pracownikach samorządowych (Dz.U. 1990 r., Nr 32, poz. 191 ze zm.).

15 J. Sługocki, Opieka nad zabytkiem..., s. 98.

16 Tekst pierwotny Dz.U. 1997 r., Nr 115, poz. 741.

17 M. Stańko, Zakres przestrzenny ochrony zabytków a ochrona uprawnień właścicielskich, „Rejent” 2002, nr 10, s. 98. 
wskazanych opinii i związany z tym brak sądowej kontroli nieuwzględnienia stanowiska wojewódzkiego konserwatora zabytków, dokonywanie przekształceń własnościowych samorządowych zabytków nieruchomych pozostawało w wyłącznej dyspozycji tych jednostek. Warto także zwrócić uwagę, że zgodnie z art. art. 68 ust. 3 u.g.n. oraz art. 73 ust. 4 u.g.n. cenę nieruchomości lub jej części wpisanej do rejestru zabytków oraz opłaty z tytułu użytkowania wieczystego tego rodzaju nieruchomości obniża się o 50 procent. Ponadto jednostki samorządowe mogły i nadal mają prawo podwyższać lub obniżać, za zgodą właściwych rad lub sejmiku, powyższe bonifikaty. Stwierdzić zatem można, że zakres samodzielności jednostek samorządu terytorialnego dotyczący dysponowania nieruchomościami wpisanymi do rejestru był bardzo szeroki. Stan taki przyczyniać się mógł do różnego rodzaju nieprawidłowości związanych $\mathrm{z}$ obrotem gruntami zabytkowymi. Biorąc pod uwagę „odpaństwowe” pochodzenie mienia samorządowego, a także konstytucyjny obowiązek strzeżenia dziedzictwa narodowego ${ }^{18}$, wyłączenie transakcji dotyczących samorządowych nieruchomości wpisanych do rejestru zabytków spod kognicji organów konserwatorskich ocenić należało negatywnie. Funkcjonujący od dnia 17 listopada 2003 r. wymóg uzyskania pozwolenia wojewódzkiego konserwatora zabytków na dokonywanie czynności prawnych dotyczących także samorządowych nieruchomości wpisanych do rejestru zabytków wydaje się zatem $\mathrm{w}$ pełni uzasadniony. Pozwolenie to wydawane jest w trybie określonym w rozdziale 9 „Postanowienia” działu II kodeksu postępo-wania administracyjnego ${ }^{19}$. Konieczność uzyskania wskazanego postanowienia wojewódzkiego konserwatora zabytków umożliwia sądową kontrolę legalności czynności prawnych podejmowanych przez jednostki samorządu terytorialnego. Należy jednak podkreślić, że przepis art. 13 ust. 4 u.g.n. nie obejmuje wszystkich nieruchomości o walorach zabytkowych pozostających w kręgu zainteresowań konserwatora zabytków $^{20}$. Wymóg uzyskania pozwolenia dotyczy wyłącznie nieruchomości wpisanych do rejestru zabytków. Tym czasem wiele nieruchomości spełnia ustawowe przesłanki objęcia ich ochroną konserwatorską, ale $\mathrm{z}$ różnych względów nie zostały one ujęte $\mathrm{w}$ rejestrze zabytków. Wymóg uzyskania zgody konserwatora zabytków na dokonanie danej czynności prawnej nie dotyczy także sytuacji gdy postępowanie o wpis do rejestru jest $\mathrm{w}$ toku, bądź zabytek wpisany jest jedynie do gminnej ewidencji za-

18 Szerzej zob. J. Sługocki, Europejski system ochrony dziedzictwa kulturowego a ochrona dziedzictwa narodowego w Polsce (wybrane zagadnienia), [w:] Dziesięć lat polskich doświadczeń w Unii Europejskiej. Problemy prawno administracyjne, tom I, red. J. Sługocki, Wrocław 2014, s. 583-594.

19 Teksty jedn. Dz.U. z 2016, poz. 23.

20 E. Bończak-Kucharczyk, Ustawa o gospodarce nieruchomościami. Komentarz, Warszawa 2014, LEX nr 451109. 
bytków. Tak wąskie określenie przewidzianej na gruncie ustawy o gospodarce nieruchomościami ochrony nieruchomości o znaczeniu dla kultury polskiej wydaje się istotnym pominięciem, mogącym skutkować uszczupleniem w przyszłości zasobów dziedzictwa narodowego. Wydaje się bowiem, że wolą ustawodawcy było objęcie ochroną zabytków w szerokim rozumieniu (zabytków w znaczeniu materialnym), a nie tylko zabytków wpisanych do rejestru. Świadczy o tym sam tytuł ustawy: „o ochronie zabytków i opiece nad zabytkami”, a także zawarta w art. 3 pkt 1 ustawowa definicja zabytku. Określenie tam zawarte wskazuje, iż rozstrzygające dla objęcia ochroną są przesłanki materialne danej nieruchomości (lub rzeczy ruchomej) wyrażające się w posiadanej wartości historycznej, artystycznej lub naukowej, z uwagi na co ich zachowanie leży w interesie społecznym. Stanowisko takie wyrażono w wyroku Wojewódzkiego Sądu Administracyjnego w Kielcach z dnia 9 grudnia 2010 r. ${ }^{21}$, w którym stwierdzono, że jeżeli obiekt spełnia przesłanki ustawowe to jest on zabytkiem w znaczeniu materialnym, fakt ten wynika $\mathrm{z}$ właściwości samego obiektu, a nie z decyzji administracyjnej. Jednocześnie Sąd podkreślił, że decyzja o wpisie do rejestru zabytków na charakter konstytutywny, tworzący nowy stan prawny w zakresie ochrony konserwatorskiej, a jej skutki nie rozciągają się na okres przed jej wydaniem ${ }^{22}$. Wydaje się, że prawo powinno obejmować ochroną konserwatorską nie tylko dokonywanie umów (sprzedaż, zamiana, darowizna lub oddanie w użytkowanie wieczyste nieruchomości) dotyczących nieruchomości wpisanych do rejestru zabytków, ale także zawierać „instrumenty ochronne” odnoszące się do nieruchomości stanowiących zabytki w znaczeniu materialnym, w szczególności jeżeli toczy się postępowanie w sprawie wpisania do rejestru lub nieruchomość ujęta została w gminnej ewidencji zabytków. $\mathrm{W}$ tym miejscu warto odwołać się do postanowieńn ${ }^{23}$ ustawy o ochronie dóbr kultury z 1962 r., która przewidywała możliwość podjęcia określonych działań przez wojewódzkiego konserwatora zabytków w stosunku do dóbr kultury jeszcze nie wpisanych do rejestru zabytków, jeżeli istniały podstawy do takiego wpisu. Działania te traciły ważność z mocy prawa, jeżeli w ciągu trzech miesięcy od ich podjęcia nie nastąpił wpis do rejestru zabytków. Wydaje się, iż wprowadzenie zbliżonych rozwiązań do obowiązującego porządku prawnego czyniłoby zadość wymogom ochrony zabytków i uniemożliwiałoby jednostkom samorządu terytorialnego zbywanie samorządowych zabytków nieruchomych niewpisanych do rejestru poza jakąkolwiek kontrolą konserwatora zabytków. Proponowane rozwiązania prawne stanowiłyby pewne ograniczenie samodzielności

21 Sygn. akt II SA/Ke 665/10, LEX nr 753336.

22 Tamże.

23 Por. art. 29 w zw. z art. 28 u.o.d.k. 
wspólnot samorządowych, jednakże z punktu widzenia interesu publicznego i wskazań Konstytucji RP (głównie art. 5) uznać należałoby je za uzasadnione i korzystne.

\section{Ochrona zabytków w planowaniu i zagospodarowaniu przestrzennym}

Dla zapewnienia realnej ochrony zabytków nieruchomych istotną rolę ogrywa umieszczenie tej problematyki w aktach planowania przestrzennego. Zgodnie z ustawą z dnia 27 marca 2003 r. o planowaniu i zagospodarowaniu przestrzennym ${ }^{24} \mathrm{w}$ działalności tej uwzględnia się zwłaszcza wymagania ochrony dziedzictwa kulturowego i zabytków oraz dóbr kultury współczesnej. Z kolei przepis art. 4 pkt 6 u.o.z.o.z. stanowi, że ochrona zabytków polega m.in. na uwzględnianiu zadań ochronnych w planowaniu i zagospodarowaniu przestrzennym. Analiza kształtowania się przepisów u.o.z.o.z. wskazuje na wzrost znaczenia problematyki ochrony zabytków w sferze planowania przestrzennego. Nowelizacja z dnia 18 marca $2010 \mathrm{r}^{25}$ istotnie rozszerzyła katalog form ochrony zabytków w sferze planowania przestrzennego. Do czasu wejścia w życie powołanej noweli formą tej ochrony było jej ustalenie $\mathrm{w}$ miejscowym planie zagospodarowania przestrzennego. $\mathrm{Z}$ punktu widzenia konserwatorskiego rozwiązanie to tylko w niewielkim stopniu gwarantowało możliwość ochrony zabytków nieruchomych. Było to konsekwencją, co do zasady, nieobowiązkowego ${ }^{26}$ charakteru uchwalania miejscowych planów przestrzennych, z uwagi na co jedynie niewielki procent terytorium kraju był nimi objęty. Co więcej, zgodnie $\mathrm{z}$ art. 87 ust. 3 u.p.z.p. plany zagospodarowania przestrzennego uchwalone przed dniem 1 stycznia 1995 r. zachowały moc najpóźniej do dnia 31 grudnia 2003 r. Po tym czasie, jeżeli gmina nie uchwaliła nowego miejscowego planu, przewidziana $\mathrm{w}$ nim dotychczas ochrona zabytków nie była uwzględniana w procedurze dotyczącej planowania i zagospodarowania przestrzennego. Po dniu 1 stycznia 2004 r. nie istniała bowiem prawna możliwość zastosowania ustaleń miejscowych planów zagospodarowania przestrzennego uchwalonych przed 1 stycznia $1995 \mathrm{r}^{27}$ Obecnie

24 Tekst jedn. Dz.U. z 2015, poz. 199 ze zm.

25 Dz.U. Nr 75, poz. 474.

26 Zgodnie z art. 14 ust. 7 u.p.z.p. plan miejscowy sporządza się obowiązkowo, jeżeli wymagają tego odrębne przepisy.

27 Por. wyrok WSA w Lublinie z dnia 15 grudnia 2009 r., II SA/Lu 717/09, LEX nr 584141. 
formą ochrony zabytków w sferze planowania i zagospodarowania przestrzennego jest - oprócz ustalenia ochrony w planie miejscowym ustalenie takiej ochrony w decyzji o ustaleniu lokalizacji inwestycji celu publicznego, decyzji o warunkach zabudowy, decyzji o zezwoleniu na realizację inwestycji drogowej ${ }^{28}$, decyzji o ustaleniu lokalizacji linii kolejowej ${ }^{29}$ lub decyzji o zezwoleniu na realizację inwestycji w zakresie lotniska użytku publicznego ${ }^{30}$. Ponadto nowela z 2010 r. zobowiązała właściwe podmioty publiczne do uwzględniania ochrony zabytków w planie zagospodarowania przestrzennego morskich wód wewnętrznych, morza terytorialnego oraz wyłącznej strefy ekonomicznej.

$\mathrm{Z}$ punktu widzenia ochrony zabytków podstawowe znaczenie mają ustalenia miejscowego planu zagospodarowania przestrzennego, który stanowić może „instrument kształtowania charakteru i funkcji terenu” ${ }^{31}$. Plan ten będąc aktem prawa miejscowego jest bowiem podstawą podejmowania władczych rozstrzygnięć z zakresu nadzoru konserwatorskiego $^{32}$. Zgodnie $\mathrm{z}$ art. 19 ust. 3 u.o.z.o.z. w miejscowym planie zagospodarowania przestrzennego ustala się, w zależności od potrzeb, strefy ochrony konserwatorskiej obejmujące obszary, na których obowiązują określone ustaleniami tego planu ograniczenia, zakazy i nakazy. Ustalenia te mają na celu ochronę znajdujących się na danym obszarze zabytków nieruchomych. Znaczenie miejscowego planu podkreśla także fakt, iż stanowi on formę „samorządowej” ochrony otoczenia zabytków nieruchomych wpisanych do rejestru. W związku z tym miejscowy plan pośrednio chroni także widok na zabytek. Ustawa o ochronie zabytków i opiece nad zabytkami z 2003r. nie przewiduje bowiem expressis verbis ochrony widoku na zabytek. Obowiązująca wcześniej ustawa z 1962 r. stanowiła natomiast w art. 27, że bez zezwolenia właściwego wojewódzkiego konserwatora zabytków nie wolno było zabytków przerabiać, odnawiać, rekonstruować, konserwować, zabudowywać, odbudowywać, zdobić, uzupełniać, rozkopywać ani dokonywać żadnych innych zmian, o ile mogłyby one przyczynić się do zeszpecenia otoczenia zabytku nieruchomego lub widoku na ten zabytek. Pominięcie w obowiązującej obecnie ustawie kwestii ochrony widoku na zabytek nieruchomy ocenić należy negatywnie. Zapewnienie dogodnego widoku na zabytek nieruchomy z pewnością składa się na

28 Zob. ustawa z dnia 10 kwietnia 2003 r. o szczególnych zasadach przygotowania i realizacji inwestycji w zakresie dróg publicznych, (tekst jedn. Dz.U. z 2015, poz. 2031).

29 Ustawa z dnia 19 września 2007 r. o zmianie ustawy o transporcie kolejowym oraz niektórych innych ustaw, (Dz.U. Nr 191, poz. 1374).

30 Ustawa z dnia 12 lutego 2009 r. o szczególnych zasadach przygotowania i realizacji inwestycji w zakresie lotnisk użytku publicznego, (Dz.U. Nr 42, poz. 340 ze zm.).

31 P. Dobosz, Administracyjnoprawne instrumenty ksztattowania ochrony zabytków, Kraków 1997,s. 172.

32 J. Sługocki, Opieka nad zabytkiem..., s. 152. 
jego estetyczną wartość, a także przyczynia się do lepszego, powszechnego odbioru estetycznego zabytku. Zabytek, jego otoczenie oraz widok na niego powinny tworzyć spójny i harmonijny obraz. Zabytki nieruchome i skorelowane z nimi otoczenie bardzo często stają się wręcz wizytówką, znakiem firmowym danej okolicy. Trudno zatem zgodzić się na działania podejmowane wokół zabytku, które szpecą jego otoczenia lub widok na niego. Uwzględnianie otoczenia zabytku nieruchomego w miejscowym planie ocenić należy pozytywnie, podkreślając jednocześnie, że plany te nie obejmują terytorium całego kraju, a także okoliczność, że ochronie podlega wyłącznie otoczenie zabytków wpisanych do rejestru zabytków. Ustawa nie przewiduje bowiem uwzględniania $\mathrm{w}$ planie miejscowym ochrony otoczenia innych zabytków nieruchomych, znajdujących się w gminnej ewidencji zabytków. Ograniczenie ochrony prawnej wyłącznie do otoczenia zabytków wpisanych do rejestru wydaje się zarówno z punktu widzenia estetycznego, jak i konserwatorskiego, a także dążenia do zapewnienia ładu przestrzennego, błędne.

Ochronę zabytków i ich otoczenia, zgodnie z art. 19 ust. 1 u.o.z.o.z. uwzględnia się także w studium uwarunkowań i kierunków zagospodarowania przestrzennego gminy. Uchwalenie studium jest obowiązkowe w granicach administracyjnych gminy, ale jego postanowienia nie stanowią formy ochrony zabytków. Zgodnie z art. 9 ust. 5 u.p.z.p. akt ten nie obowiązuje erga omnes, nie jest bowiem aktem prawa miejscowego. Postanowienia studium, w przypadku braku miejscowego planu, nie mogą zatem zapewnić rzeczywistej ochrony zabytków. Jeżeli gmina posiada gminny program opieki nad zabytkami, ustalenia tego programu uwzględnia się zarówno w studium, jak i miejscowym planie zagospodarowania przestrzennego.

Jeżeli w gminie nie uchwalono miejscowego planu zagospodarowania przestrzennego, określenie sposobów zagospodarowania i warunków zabudowy danego terenu następuje albo w drodze decyzji o lokalizacji inwestycji celu publicznego albo, w stosunku do innych inwestycji, $\mathrm{w}$ drodze decyzji o warunkach zabudowy. W odniesieniu do inwestycji celu publicznego o znaczeniu krajowym i wojewódzkim decyzje wydaje wójt, burmistrz albo prezydent miasta w uzgodnieniu z marszałkiem województwa. W przypadku ustalenia lokalizacji inwestycji celu publicznego o znaczeniu powiatowym i gminnym wójt, burmistrz albo prezydent miasta wydaje decyzje bez konieczności dokonywania uzgodnień. Jeżeli inwestycja celu publicznego wykracza poza obszar jednej gminy decyzję lokalizacyjną wydaje wójt, burmistrz albo prezydent miasta, na którego obszarze właściwości znajduje się największa część terenu, na którym ma być realizowana dana inwestycja, w porozumieniu z zainteresowanymi wójtami, burmistrzami albo prezydentami miast. Natomiast decyzję o warunkach zabudowy wydaje, za wyjątkiem inwestycji znajdujących 
się na terenach zamkniętych ${ }^{33}$, wójt, burmistrz albo prezydent miasta po uzgodnieniu $\mathrm{z}$ organami wskazanymi w art. 53 ust. 4 u.p.z.p. oraz uzyskaniu uzgodnień lub decyzji wymaganych odrębnymi przepisami ${ }^{34}$. Zgodnie z ustawą o ochronie zabytków ${ }^{35}$ we wskazanych decyzjach uwzględnia się ochronę zabytków nieruchomych wpisanych do rejestru i ich otoczenia oraz ochronę innych zabytków nieruchomych, znajdujących się w gminnej ewidencji zabytków. Decyzje o warunkach zabudowy i zagospodarowania terenu wydawane są wówczas po uzgodnieniu $\mathrm{z}$ wojewódzkim konserwatorem zabytków. $Z$ uwagi na fakt, iż większość procesów inwestycyjnych w Polsce podejmowanych jest na podstawie decyzji o warunkach zabudowy i zagospodarowania terenu (czyli decyzji o lokalizacji inwestycji celu publicznego lub decyzji o warunkach zabudowy) przepisy dodane w 2010 r. wprowadzające wymóg uwzględniania w tych decyzjach administracyjnych względów ochrony zabytków ocenić należy pozytywnie. Przepisy te budzą jednak pewne wątpliwości interpretacyjne. Przede wszystkim uwagę zwraca konieczność uwzględniania ochrony „innych zabytków nieruchomych, znajdujących się w gminnej ewidencji zabytków". Gminna ewidencja zabytków, w odróżnieniu od wpisu do rejestru zabytków, nie stanowi formy ochrony zabytków. Konieczność uwzględniania jej postanowień przy wydawaniu tzw. decyzji lokalizacyjnych wskazuje, że w obecnym stanie prawnym wpis do ewidencji wpływa na prawa i obowiązki właścicieli nieruchomości zabytkowych. Ustawodawca nie określił jednak formy i sposobu umieszczania zabytków nieruchomych w ewidencji zabytków. Przepis art. 22 ust. 4. u.o.z.o.z. stanowi wyłącznie, że wójt (burmistrz, prezydent miasta) prowadzi gminną ewidencję zabytków w formie zbioru kart adresowych zabytków nieruchomych $\mathrm{z}$ terenu gminy. Nowelizacja ustawy o ochronie zabytków i opiece nad zabytkami z 2010 r. istotnie rozszerzyła funkcje oraz zakres przedmiotowy gminnej ewidencji. Dotychczas w gminnej ewidencji ujmowane były wyłącznie obiekty objęte już ewidencją wojewódzką, z uwagi na co gminny spis (ewidencja) miał wtórny, wewnętrzny charakter. Obecnie gminna ewidencja obejmuje: 1) zabytki nieruchome wpisane do rejestru zabytków; 2) inne zabytki nieruchome znajdujące się w wojewódzkiej ewidencji zabytków; 3) inne zabytki nieruchome wyznaczone przez wójta (burmistrza, prezydenta miasta) w porozumieniu $\mathrm{z}$ wojewódzkim konserwatorem zabytków $^{36}$. Podzielić zatem należy stanowisko, zgodnie z którym nowela z 2010 roku dopuszczając możliwość wpisywania do ewidencji „innych zabyt-

33 Decyzje dotyczące inwestycji podejmowanych na terenach zamkniętych wydaje wojewoda.

34 Por. art. 69 u.p.z.p.

35 Por. art. 18 u.o.z.o.z.

36 Por. art. 22 ust. 5 u.o.z.o.z. 
ków" de facto usytuowała gminną ewidencję w hierarchii przed ewidencją wojewódzką ${ }^{37}$, czyniąc $\mathrm{z}$ gminnej ewidencji nienazwaną prawnie formę ochrony zabytków" ${ }^{\prime 38}$. W obecnym stanie prawnym gminna ewidencja stanowi zatem, mimo iż nie jest formą ochrony zabytków, samodzielną podstawę kształtowania sytuacji prawnej podmiotów spoza systemu organów administracji publicznej. Wskazuje na to także przepis art. 39 ust. 3 P.b. ${ }^{39}$, zgodnie z którym w stosunku do obiektów budowlanych oraz obszarów niewpisanych do rejestru zabytków, a ujętych w gminnej ewidencji zabytków, pozwolenie na budowę lub rozbiórkę obiektu budowlanego wydaje właściwy organ w uzgodnieniu z wojewódzkim konserwatorem zabytków. W tym miejscu należy zauważyć, iż zgodnie ze stanowiskiem $\mathrm{NSA}^{40}$ organ prowadzący postępowanie $\mathrm{w}$ trybie przepisu art. 59 ust. 1 i 2 u.p.z.p. dla zamierzenia inwestycyjnego obejmującego obiekt, którego dotyczy toczące się postępowanie o wpis do rejestru, nie musi dokonywać uzgodnienia Z wojewódzkim konserwatorem zabytków. Z uwagi na to, w ocenie Sądu, $\mathrm{w}$ takiej sytuacji nie zachodzą przesłanki do zawieszania postępowania $\mathrm{w}$ trybie przewidzianym w K.p.a. Wskazana kwestia budzi jednak pewne wątpliwości prawne. Ochronie prawnej podlegają bowiem „inne zabytki nieruchome, znajdujące się w gminnej ewidencji zabytków", a odmawia się takiej ochrony zabytkom, co do których toczy się już postępowanie w sprawie wpisu do - stanowiącego formę ochrony zabytków - rejestru. Przytoczone stanowisko Sądu może powodować, że nieruchomości stanowiące zabytki w znaczeniu materialnym, ulegną nieodwracalnemu zniszczeniu. Odmowa zawieszenia postępowania inwestycyjnego może przyczynić się do strat w dziedzictwie kultury, którego zachowanie i ochrona leży $\mathrm{w}$ interesie społecznym (interesie publicznym). Przyjęcie przedstawionego stanowiska Sądu wydaje się zatem trudne do pogodzenia z określonymi w ustawie celami ochrony zabytków, które polegać mają m.in. na podejmowaniu przez organy administracji publicznej działań mających na celu trwałe zachowanie zabytków oraz zapobieganie zagrożeniom mogącym spowodować uszczerbek dla ich wartości.

Uwzględnianie w decyzjach o warunkach zabudowy i zagospodarowania terenu ochrony zabytków nieruchomych wpisanych do gminnej ewidencji zabytków budzi wątpliwości także z uwagi na postanowienia art. 63 ust. 2 u.p.z.p. Przepis ten deklaruje, że wskazana decyzja nie rodzi praw do terenu oraz nie narusza prawa własności i uprawnień osób trzecich. Infor-

37 P. Antoniak P., M. Cherka, [w:] Ustawa o ochronie zabytków i opiece nad zabytkami. Komentarz, red. M. Cherka, Warszawa 2010, s. 125-126.

38 P. Antoniak, M. Cherka, op. cit., s. 126.

39 Ustawa z dnia 7 lipca 1994 r. Prawo budowlane (tekst jedn. Dz.U. 2013, poz. 1409 ze zm., zwana dalej P.b.).

40 Wyrok NSA z dnia 15 października 2010 r., II OSK 1612/09, http://orzeczenia. nsa.gov.pl (dostęp 10.06.2015). 
mację o tym zamieszcza się w jej treści. Tymczasem jeżeli teren, którego dotyczy postępowanie wpisany jest do gminnej ewidencji, decyzja wydawana jest $\mathrm{w}$ uzgodnieniu $\mathrm{z}$ wojewódzkim konserwatorem zabytków. Zdaniem J. Sługockiego, dokonywanie tego rodzaju „ustaleń ochrony” w ewidentny sposób prowadzi do określenia - w drodze omawianej decyzji administracyjnej - możliwych do podjęcia przez inwestora działań, co bezpośrednio wpływa na zakres jego praw i obowiązków. Tym samym dokonywanie „ustaleń ochrony” trudno pogodzić z dyspozycją art. 63 ust. 2 u.p.z.p p $^{41}$

Ochronę i opiekę nad zabytkami uwzględnia się, w myśl art. 18. 1. u.o.z.o.z., także w aktach stanowionych przez samorząd województwa oraz samorząd powiatowy. Na poziomie województw wartości te brane są pod uwagę przy określaniu strategii rozwoju województwa oraz w planach zagospodarowania przestrzennego województw. Z kolei powiat uwzględnia ochronę i opiekę nad zabytkami w analizach i studiach z zakresu zagospodarowania przestrzennego powiatu. Wskazane akty są aktami prawa wewnętrznego, $\mathrm{z}$ uwagi na co nie mogą stanowić podstawy władczych działań administracji publicznej ani wpływać bezpośrednio na prawa i obowiązki właścicieli lub posiadaczy zabytków nieruchomych.

Zachowania zabytków dotyczą także samorządowe programy opieki nad nimi. Przepis art. 87 ust. 1 u.o.z.o.z. stanowi, że zarząd województwa, powiatu lub wójt (burmistrz, prezydent miasta) sporządza na okres 4 lat odpowiednio wojewódzki, powiatowy lub gminny program opieki nad zabytkami. Wskazane programy przyjmują odpowiednio sejmiki województw, rady powiatów lub rady gmin po uzyskaniu opinii wojewódzkiego konserwatora zabytków. Akty te ogłaszane są w wojewódzkim dzienniku urzędowym. Zgodzić należy się z poglądem doktryny ${ }^{42}$ i orzecznictwa sądów administracyjnych ${ }^{43}$, że uchwały w sprawie programu opieki nad zabytkami jednostek samorządu terytorialnego nie stanową aktów prawa miejscowego. Ich moc wiążąca ograniczona jest wyłącznie do organu wykonawczego, względnie innych podmiotów znajdujących się wewnątrz struktury organizacyjnej danej jednostki samorządu terytorialnego. Podstawowe cele, które realizować mają omawiane programy określa ust. 2

41 J. Stugocki, Opieka nad zabytkiem..., s. 154.

42 P. Dobosz, [w:] Ustawa o samorządzie gminnym. Komentarz, red. P. Chmielnicki, Warszawa 2013, s. 217; A. Wilczyńska, Program opieki nad zabytkami, [w:] Encyklopedia samorządu terytorialnego dla każdego. Część 2: Zadania i kompetencje, red. M. Stahl, B. Jaworska-Dębska, Warszawa 2011, s. 441; K. Wlaźlak, Program opieki nad zabytkami, System Informacji Prawnej LEX/el. dla Samorządu Terytorialnego, Wolters Kluwer 2014.

43 Wyrok WSA w Warszawie z dnia 28 października 2011 r., IV SA/Wa 1067/11, http://orzeczenia.nsa.gov.pl (dostęp 15.06.2015); M. Chlipała, Glosa do wyroku WSA w Krakowie z 27 czerwca 2006 r. (III SA/Kr 226/06, niepubl.). Akty prawa miejscowego o charakterze wykonawczym stanowione przez zarząd powiatu, „Przegląd Prawa Publicznego" 2007, nr 3, s. 79. 
art. 87 u.o.zo.z. ${ }^{44}$. Co ciekawe, ustawodawca jako cele programu opieki nad zabytkami wskazuje w większości, w tym expressis verbis, działania składające się na ochronę zabytków. Opiekę nad zabytkami, zgodnie z ustawą o ochronie zabytków, sprawują ich właściciele lub posiadacze i to oni wydają się być naturalnie predestynowani do tworzenia tego rodzaju programów opieki. Zadaniem podmiotów publicznych jest natomiast sprawowanie ochrony nad zabytkami. Nazwa ${ }^{45}$ samorządowych programów jest zatem nieadekwatna i zawężająca w stosunku do ich treści. W literaturze zauważono, iż ustawa nie przewiduje żadnych sankcji za nieuchwalenie wskazanych programów, co może „wiązać się ze złym stanem, a nawet degradacją zabytków, które to zjawiska negatywnie wpłyną na wizerunek przestrzeni i konkurencyjność danej jednostki samorządu terytorialnego" ${ }^{46}$. Samorządowe programy opieki nad zabytkami uznać należy za ważny instrument polityki samorządowej, wskazujący na obrane kierunki i przyjęte w sferze ochrony i opieki nad zabytkami wartości.

\section{Ochrona krajobrazu jako zadanie jednostek samorządu terytorialnego}

Omawiając problematykę ochrony zabytków nieruchomych przez samorząd terytorialnego należy zwrócić uwagę na rozwiązania prawne wprowadzone ustawą z dnia 24 kwietnia 2015 r. o zmianie niektórych ustaw w związku ze wzmocnieniem narzędzi ochrony krajobrazu ${ }^{47}$. Wskazany

44 Programy te mają na celu, w szczególności: 1) włączenie problemów ochrony zabytków do systemu zadań strategicznych, wynikających z koncepcji przestrzennego zagospodarowania kraju; 2) uwzględnianie uwarunkowań ochrony zabytków, w tym krajobrazu kulturowego i dziedzictwa archeologicznego, łącznie z uwarunkowaniami ochrony przyrody i równowagi ekologicznej; 3) zahamowanie procesów degradacji zabytków i doprowadzenie do poprawy stanu ich zachowania; 4) wyeksponowanie poszczególnych zabytków oraz walorów krajobrazu kulturowego; 5) podejmowanie działań zwiększających atrakcyjność zabytków dla potrzeb społecznych, turystycznych i edukacyjnych oraz wspieranie inicjatyw sprzyjających wzrostowi środków finansowych na opiekę nad zabytkami; 6) określenie warunków współpracy z właścicielami zabytków, eliminujących sytuacje konfliktowe związane z wykorzystaniem tych zabytków; 7) podejmowanie przedsięwzięć umożliwiających tworzenie miejsc pracy związanych z opieką nad zabytkami.

45 W odróżnieniu od Krajowego programu ochrony zabytków i opieki nad zabytkami tworzonego przez administrację rządową, por. art. 84 u.o.z.o.z.

46 K. Wlaźlak, Program opieki nad zabytkami, System Informacji Prawnej LEX/el. dla Samorządu Terytorialnego, Wolters Kluwer 2014.

47 Dz.U. poz. 774. 
akt prawny stanowić ma pełną implementację postanowień ratyfikowanej przez Polskę Europejską Konwencję Krajobrazową sporządzonej w dniu 20 października 2000 roku we Florencji ${ }^{48}$. Ustawa z roku 2015 wprowadziła narzędzia sprzyjające ochronie krajobrazu oraz powszechnej jego identyfikacji i waloryzacji. Dodany na jej mocy przepis art. 37a ustawy o planowaniu i zagospodarowaniu przestrzennym umożliwia radzie gminy ustalenie w formie uchwały zasad i warunków sytuowania obiektów małej architektury, tablic i urządzeń reklamowych oraz ogrodzeń, ich gabarytów, standardów jakościowych oraz rodzajów materiałów budowlanych, z jakich mogą być one wykonane. Uchwały te stanową akty prawa miejscowego, czyli mogą być podstawą władczego rozstrzygania o prawach i obowiązkach osób trzecich. $Z$ przepisem art. 37a u.p.z.p. koresponduje, dodany także na mocy ustawy z 24 kwietnia 2015 r., przepis art. 19 ust. 1 b ustawy o ochronie zabytków. Zgodnie z nim, w uchwale określającej zasady i warunki sytuowania obiektów małej architektury, tablic i urządzeń reklamowych oraz ogrodzeń, uwzględnia się w szczególności ochronę zabytków nieruchomych wpisanych do rejestru i ich otoczenia, a także ochronę innych zabytków nieruchomych znajdujących się w gminnej ewidencji zabytków. Z kolei na organy samorządu województwa nałożono obowiązek sporządzania, nie rzadziej niż raz na 20 lat, audytu krajobrazowego ${ }^{49}$. Dokument ten określać na min. lokalizację krajobrazów priorytetowych. Krajobraz priorytetowy jest nowym pojęciem ustawowym oznaczającym krajobraz szczególnie cenny dla społeczeństwa ze względu na swoje wartości przyrodnicze, kulturowe, historyczne, architektoniczne, urbanistyczne, ruralistyczne lub estetyczno-widokowe, i jako taki wymagający zachowania lub określenia zasad i warunków jego kształtowania. Wydaje się zatem, iż zabytki nieruchome stanowić będą istotny element krajobrazu priorytetowego województw. Audyt krajobrazowy wskazywać ma także lokalizację i granice, tworzonych w drodze uchwały rady gminy, parków kulturowych. Parki kulturowe tworzone są, w myśl art.16 ust. 1 u.o.z.o.z, w celu ochrony krajobrazu kulturowego oraz zachowania wyróżniających się krajobrazowo terenów z zabytkami nieruchomymi charakterystycznymi dla miejscowej tradycji budowlanej i osadniczej. Na mocy art. 13 ustawy o wzmocnieniu narzędzi ochrony krajobrazu nałożono na sejmiki poszczególnych województw obowiązek uchwalenia pierwszych audytów krajobrazowych $\mathrm{w}$ terminie 3 lat od dnia wejścia w życie ustawy (czyli od dnia 11 września 2015 r.). Sankcją za brak realizacji wskazanego obowiązku jest opracowanie i przyjęcie audytu dla danego województwa - w drodze zarządzenia zastępczego - przez wojewodę. Koszty sporządzenia audytu krajobrazowego w trybie nadzorczym ponosić będzie właściwy samorząd wojewódz-

48 Dz.U. 2006, Nr 14, poz. 98.

49 Por. art. 38 i art. 38a u.p.z.p. 
twa. Z punktu widzenia ochrony zabytków oraz dążenia do zapewnienia estetycznej przestrzeni publicznej przepisy wprowadzone ustawą z $2015 \mathrm{r}$. o wzmocnieniu narzędzi ochrony krajobrazu ocenić należy pozytywnie.

\section{Podsumowanie}

Dwadzieścia pięć lat istnienia samorządu terytorialnego wskazuje, że ochrona zabytków nieruchomych odgrywa istotną rolę w działalności tych wspólnot. Omawiana problematyka ważna jest zarówno z punku widzenia interesów jednostek, jak i z uwagi na dążenie do zachowania cennych dóbr kultury dla przyszłych pokoleń, wpisuje się $\mathrm{w}$ realizację zasady solidarności międzypokoleniowej i zasady zrównoważonego rozwoju ${ }^{50}$. Podstawową rolę odgrywa działalność podejmowana przez gminy, w szczególności uwzględnianie ochrony zabytków nieruchomych w sferze planowania przestrzennego. Gminy mogą bowiem w drodze miejscowych planów zagospodarowania przestrzennego ustalać strefy ochrony konserwatorskiej, na których obowiązują określone ustaleniami tego planu ograniczenia, zakazy i nakazy ${ }^{51}$. Tego rodzaju władcza ingerencja w prawa i obowiązki osób posiadających tytuł prawny do objętych planem nieruchomości nie może być jednak nadmierna ani nosić cech dowolności. Działania takie uniemożliwiałyby bowiem sprawne prowadzenie procesów inwestycyjnych. Podejmowane przez gminę oraz pozostałe jednostki samorządu terytorialnego działania powinny być przemyślane i zmierzać do zachowania i zapobiegania zagrożeniom mogącym spowodować uszczerbek dla zabytków nieruchomych. Jednostki samorządu terytorialnego szeroko rozumianą ochroną powinny obejmować nie tylko zabytki wpisane do rejestru (oraz ich otoczenie), ale także nieruchomości stanowiące zabytki w znaczeniu materialnym. Obiekty te w przyszłości mogą bowiem zostać wpisane do urzędowego spisu zabytków i dlatego ich zachowanie w niepogorszonym stanie jest uzasadnione. Wniosek taki wynika także z przepisu art. 108 ust. 1 u.o.z.o.z., zgodnie z którym karze podlega niszczenie lub uszkadzanie zabytków, a nie tylko zabytków wpisanych do rejestru. W literaturze zauważono, że brzmienie tak zredagowanego przepisu wskazuje, że wolą ustawodawcy jest objęcie ochroną prawną wszystkich zabytków, a nie np. tylko tych, które zostały wpisane do rejestru lub objęte inną formą ochrony

50 P. Korzeniowski, Zrównoważony rozwój, [w:] Encyklopedia samorządu terytorialnego dla każdego. Część 1: Ustrój, red. M. Stahl, B. Jaworska-Dębska, Warszawa 2010, s. 304.

51 Por. art. 19 ust. 3 u.o.z.o.z. 
prawnej. Przedmiotem ochrony jest zatem nienaruszalność zabytku niezależnie także od tego, czyją stanowi on własnośćc ${ }^{52}$. Zachowanie wskazanych „pomników kultury” leży bowiem we wspólnym interesie z uwagi na ich wartość historyczną, estetyczną, artystyczną lub naukowo-poznawczą.

\section{Bibliografia}

Antoniak P., Cherka M., [w:] Ustawa o ochronie zabytków i opiece nad zabytkami. Komentarz, red. Cherka M., Warszawa 2010.

Bończak-Kucharczyk E., Ustawa ogospodarce nieruchomościami. Komentarz, Warszawa 2014.

Chlipała M., Glosa do wyroku WSA w Krakowie z 27 czerwca 2006 r. (III SA/Kr 226/06, niepubl.). Akty prawa miejscowego o charakterze wykonawczym stanowione przez zarząd powiatu, „Przegląd Prawa Publicznego" 2007, nr 3.

Dobosz P., Administracyjnoprawne instrumenty ksztattowania ochrony zabytków, Kraków 1997.

Dobosz P., [w:] Ustawa o samorzadzie gminnym. Komentarz, red. Chmielnicki P., Warszawa 2013.

Korzeniowski P., Zrównoważony rozwój, [w:] Encyklopedia samorzadu terytorialnego dla każdego. Część 1: Ustrój, red. Stahl M., Jaworska-Dębska B., Warszawa 2010.

Pruszyński J., Dziedzictwo kultury Polski. Jego straty i ochrona prawna, tom II, Kraków 2001.

Sługocki J., Europejski system ochrony dziedzictwa kulturowego a ochrona dziedzictwa narodowego w Polsce (wybrane zagadnienia), [w:] Dziesięć lat polskich doświadczeń w Unii Europejskiej. Problemy prawno-admi- nistracyjne, tom I, red. Sługocki J., Wrocław 2014.

Sługocki J., Opieka nad zabytkiem nieruchomym. Problemy administracyjnoprawne, Warszawa 2014.

Sługocki J., Problemy prawne ochrony zabytkowych parków dworsko-pałacowych [w:] Dobra chronione w prawie administracyjnym, Łódź 2014.

Sługocki J., Próba doprecyzowania pojęć prawnych na przykładzie ustawy z 23 lipca 2003 r. o ochronie zabytków i opiece nad zabytkami, www.wuwr. com.pl/online-texts/download/27. html (dostęp 10.07.2015).

Stańko M., Zakres przestrzenny ochrony zabytków a ochrona uprawnień właścicielskich, „Rejent” 2002, nr 10.

Trzciński M., Uwagi o ochronie zabytków na marginesie wyroku Sadu Rejonowego w Jeleniej Górze $z$ dnia 1 grudnia 2014 r. (sygn. akt II K 348/14), „Zeszyty Naukowe Sądownictwa Administracyjnego" 2015, $\mathrm{nr} 3$.

Wilczyńska A., Program opieki nad zabytkami, [w:] Encyklopedia samorządu terytorialnego dla każdego. Część 2: Zadania i kompetencje, red. Stahl M., Jaworska-Dębska B., Warszawa 2011.

Wlaźlak K., Program opieki nad zabytkami, System Informacji Prawnej LEX/ el. dla Samorządu Terytorialnego, Wolters Kluwer, 2014.

52 M. Trzciński, Uwagi o ochronie zabytków na marginesie wyroku Sądu Rejonowego w Jeleniej Górze z dnia 1 grudnia 2014 r. (sygn. akt II K 348/14), „Zeszyty Naukowe Sądownictwa Administracyjnego" 2015, nr 3, s. 76 i n. 